\title{
Effect of Different Level of Nitrogen Fertilizer on Growth, Yield and Yield Component of Tomato (Lycopersicon Esculentum Mill.) at West Showa Zone, Oromia, Ethiopia
}

\author{
Nemomsa Beyene*, Tilahun Mulu \\ Department of Plant Sciences, Ambo University, Ambo, Ethiopia \\ Email address: \\ nemomsa.beyene9@gmail.com (N. Beyene), tilahunmulu@gmail.com (T. Mulu) \\ ${ }^{*}$ Corresponding author
}

\section{To cite this article:}

Nemomsa Beyene, Tilahun Mulu. Effect of Different Level of Nitrogen Fertilizer on Growth, Yield and Yield Component of Tomato (Lycopersicon Esculentum Mill.) at West Showa Zone, Oromia, Ethiopia. Agriculture, Forestry and Fisheries.

Vol. 8, No. 5, 2019, pp. 100-104. doi: 10.11648/j.aff.20190805.12

Received: August 13, 2019; Accepted: October 8, 2019; Published: October 21, 2019

\begin{abstract}
The field experiment was conducted in West showa zone, Toke kutaye district of Ormia region, Ethiopia with the objective to determine the optimum nitrogen fertilizer rate on different growth parameters, yield and yield component of tomato crop. To attain the objective, four level of nitrogen fertilizer Viz., 0, 50, 100, and $150 \mathrm{~kg} / \mathrm{ha}$ were used as treatments. The experiment was laid out in randomized complete block design (RCBD) with three replications. Data on plant height, number of primary branches per plant, number of leaves per plants, number of cluster per plant, number of fruits per cluster and fruit yield were collected from five plants of the middle rows of each plot and subjected to statistical analysis software (SAS) version 9.3 and LSD at 5\% was used for mean comparison. The statistical analysis showed that, there was the significant $(\mathrm{P}<0.05)$ difference among treatments for all parameters except for number of fruit per cluster. For growth variables, $150 \mathrm{~kg} / \mathrm{ha}$ revealed the highest value but there was no significant $(\mathrm{P}<0.05)$ difference between $100 \mathrm{and} 150 \mathrm{~kg} / \mathrm{ha}$ of nitrogen except for the height of the plant. The treatment $150 \mathrm{~kg} / \mathrm{ha}$ nitrogen fertilizer provided $22.41,35.57$ and $25.40 \%$ over the control treatment in height, number of leaves and number of primary branch, respectively. The treatment $150 \mathrm{~kg} / \mathrm{ha}$ nitrogen fertilizer increased the number of cluster per plant and yield of tomato fruit per hectare by 34.50 and $70.79 \%$ over the control treatment, respectively. However, there was no significant difference in both number of cluster per plant and yield per hectare between 150 and $100 \mathrm{~kg} \mathrm{~N} / \mathrm{ha}$.
\end{abstract}

Keywords: Tomato, Nitrogen Fertilizer, Yield Components, Yield

\section{Introduction}

Tomato (Lycopersicon esculentum mill) belongs to the family Solanacea, genus Lycopersicon, sub family Solanoideae and tribe Solaneae. It is widely cultivated in tropical, subtropical and temperate climates and ranks third next to potato and sweet potato in terms of world vegetable production [1] with estimated annual area coverage and total production of 164 metric million tones which was harvested from 4.73 million hectares [2].

Among vegetable crops, tomato is the most important edible and nutritious worldwide [1]. Tomato plays an important role in human nutrition by providing essential amino acids, vitamins, minerals, sugars and dietary fibers [3].
The authors also reported that the fruit contains vitamin B and $\mathrm{C}$, iron and phosphorus and its vitamin $\mathrm{C}$ content is particularly high and it is an important source of antioxidant such as lycopene. Tomato is almost always used as an essential ingredient in the diet of the people and in almost every household and usually used for preparing foods like soups, sauces, stews, salads and others, in cooked or processed form in large quantities as compared to other vegetables [4].

In Ethiopia, the highest share of commercial vegetable is taken by tomato [5]. Edossa et al. [6] indicated that the climatic and soil condition of Ethiopia allow cultivation of wide range of fruit and vegetable crops including tomato. The crop is produced at altitude range of 700 up to 2200 
meter above sea level and with about 700 to over $1400 \mathrm{~mm}$ annual rain fall on different soils and in different weather conditions in Ethiopia [7]. The average yield of tomato in Ethiopia is extremely low, 8 tone/ha compared to the world average yields which is 34 tone/ha [8]. Tomato production in Ethiopia reduced from 6298.63 hectares area coverage and 283648.27 quintals yield in $2016 / 17$ to 5235.19 hectares and $277,745.38$ quintals yield in 2017/18 cropping season [8].

The major yield reducing factors of tomato in Ethiopia are low soil fertility, erratic rainfall distribution, lack of high yielding cultivars, low soil moisture content, disease and insect pest and lack of optimum recommended fertilizer application rate [10]. Sanchez et al. [11] reported that, low fertilizer utilization and soil nutrient depletion is the major reasons for low agricultural productivity in African country particularly in Ethiopia. Among these factors, application of optimum nitrogen fertilizer rate is one of the main determinant factors which significantly affect growth and yield of tomato in Ethiopia [12].

Tomato crop is highly responsive to nitrogen fertilizer application where nitrogen availability may be limited and time of the application is critical [13]. Hokam et al. [14] reported that nitrogen promotes vegetative growth and fruit yield, favors fruit development (when applied at later growing stage) and application of proper amount of the fertilizer has a dramatic effect on tomato growth and development. So far, fertilizer rates for tomato crop was determined only at Melkasa Research Center which cannot represent agro-ecologically for other tomato growing regions of the country and no such study was done for tomato under vertisol condition [15]. Therefore, it is prudent to test different rate of nitrogen fertilizer at different topographic area. Hence, the objective of this study was to determine the optimum nitrogen fertilizer level for growth, yield and yield components of Roma VF tomato variety at Gudar area of Toke kutaye district of Oromia.

\section{Materials and Methods}

\subsection{Description of the Study Area}

The study was conducted in West Showa zone, Toke kutaye district at Guder, in 2019 under irrigation. The site is located at distance of $137 \mathrm{~km}$ to west of Addis Ababa (capital city) at $8^{\circ} 58^{\prime}$ North latitude and $37 " 46^{\prime}$ East longitude with an elevation 2101 meters above sea level. The annual range of temperature of the area is $15-40^{\circ} \mathrm{C}$, with rain fall which ranges from $1257-2000 \mathrm{~mm}$. The soil types of the area is vertisol with $\mathrm{pH}$ value of 5.5-6.5.

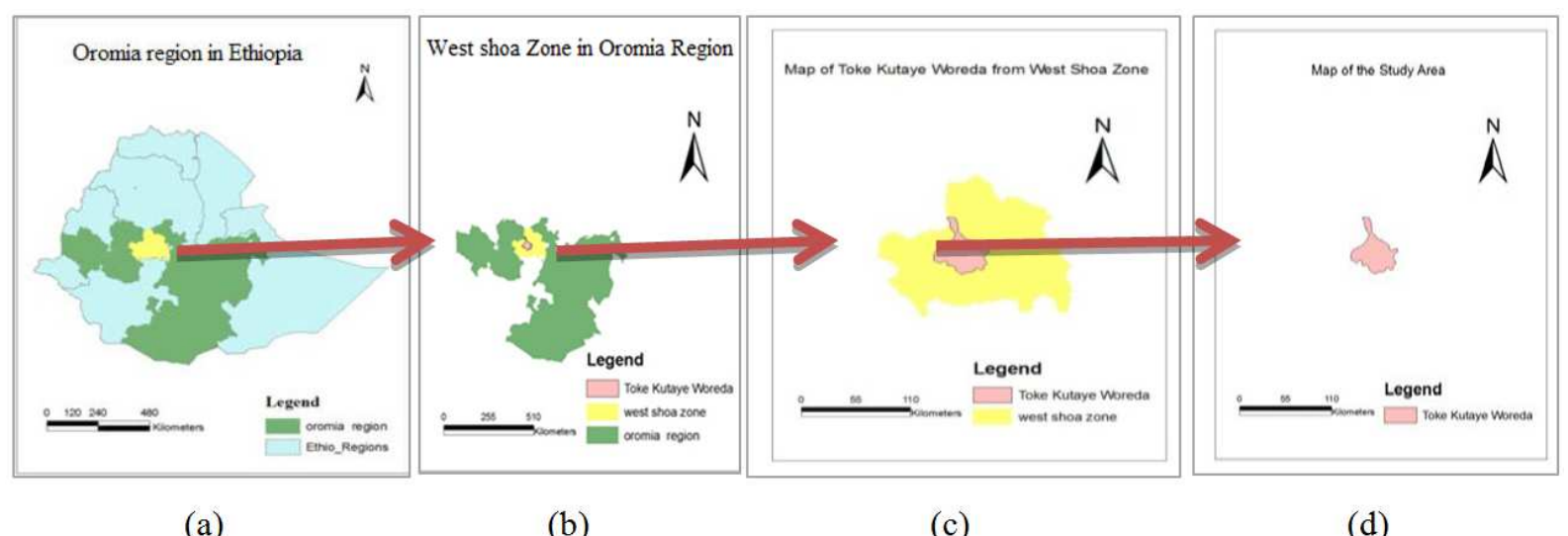

(a)

(b)

(c)

(d)

Figure 1. Map showing the study area (Oromia region in Ethiopia (A), Toke Kutaye district in Oromia region (B), study area in Toke kutaye district (C), and study area (D)).

\subsection{Treatments and Experimental Design}

Roma VF tomato variety was used for the study. The seedling was prepared a head on a well prepared seed bed. The experiment was consisted of four nitrogen fertilizer rate $(0,50,100,150 \mathrm{~kg} / \mathrm{ha})$ and arranged in randomized complete block design (RCBD) with three replications. Each plot had 3.2 meter width and 2 meter length. The spacing between the blocks and plots were $1.5 \mathrm{~m}$ and $1 \mathrm{~m}$, respectively. Four rows per plot with $0.8 \mathrm{~m}$ and $0.4 \mathrm{~m}$ between the row and the plant, respectively, was used. Each row contained five plants. The treatments were assigned to the plots randomly.

\subsection{Experimental Procedure, Data Collection and Data Analysis}

The prepared seedlings were transplanted to the experimental field on the $45^{\text {th }}$ days of nursery bed growth when the seedlings $10-12 \mathrm{~cm}$ in height. The experimental field was irrigated immediately after transplanting and irrigation was continued at two days interval throughout the growth period. At transplanting, $50 \%$ nitrogen fertilizer from the total of each treatment was added to the experimental plot and the remaining $50 \%$ was added on 46 days after transplanting. All the management practices were applied as recommend. Five plants from the middle two rows of each plot were randomly taken and tagged for data collection. Plant height, number of leaf per plant, number of primary branches, number of cluster per plant, number of fruit per cluster and fruit yield per hectare data were collected.

The collected data were subjected to SAS software version 9.3 for Analysis of Variance (ANOVA) and means comparisons for the significantly different variables were 
made among treatments using Least Significant Differences (LSD) test at 0.05 levels of significance.

\section{Result and Discussion}

\subsection{Effect of Nitrogen Fertilizer on Growth of Tomato}

The statistical analysis showed that there was significant $(\mathrm{P}<$ $0.05)$ difference among treatments in affecting the height of the plant. The longest $(61.26 \mathrm{~cm})$ and the shortest $(47.53 \mathrm{~cm})$ tomato plant was recorded from the plot treated by 150 and $0 \mathrm{~kg}$ $\mathrm{N} /$ ha, respectively, (table 1). The height of tomato plant was increased with the rate nitrogen fertilizer. However, there was no significant difference between 0 and $50 \mathrm{~kg} \mathrm{~N} / \mathrm{ha}$ in influencing the height of tomato. This result was in agreement with the result obtained by Biswas et al. [16] who revealed that the tallest plant was obtained by applying $150 \mathrm{~kg} \mathrm{~N} / \mathrm{ha}$. This study also in line with the study conducted by Najafvand et al. [17] who reported that as the amount of nitrogen fertilizer increased the height of tomato also increased. Applying $150 \mathrm{Kg} \mathrm{N} / \mathrm{ha}$ increased plant height by $22.41,19.03$ and $9.5 \%$ compared to 0 $\mathrm{kg}, 50$, and $100 \mathrm{~kg} \mathrm{~N} /$ ha treatments, respectively. Application of $100 \mathrm{~kg} \mathrm{~N} / \mathrm{ha}$ increased plant height by $14.25 \%$ compared to the control treatment which was in line with the study conducted by Gezu et al. [18] who revealed $13.6 \%$ in plant height increment compared to the control (no fertilizer application) by application of $99 \mathrm{~kg} \mathrm{~N} / \mathrm{ha}$. The increase in plant height could be due to the readily available nitrogen which promotes vegetative growth and development. Nitrogen nutrient is responsible for photosynthesis, formation of chlorophyll and nucleic acids, its absence or deficiency causes stunted growth [19], hence this nutrient responsible for accumulation of greater biomass. The result obtained in this study was in line with the results obtained by Akbar [20] who found that plant height in tomato increased with increased in nitrogen rate.

This study showed that there was significant $(\mathrm{P}<0.05)$ difference between 0 and $100 \mathrm{~kg} \mathrm{~N} / \mathrm{ha}, 0$ and $150 \mathrm{~kg} \mathrm{~N} / \mathrm{ha}, 50$ and $100 \mathrm{~kg} \mathrm{~N} / \mathrm{ha}$, and 50 and $150 \mathrm{~kg} \mathrm{~N} / \mathrm{ha}$ in influencing the number of leaves per plant. The study revealed that, as the rate of nitrogen fertilizer increased, the number of leaves per plant also increased. This result was also in agreement with the finding of Balemi [12] who reported that as nitrogen fertilizer level increases the number of tomato leaf increased. The highest leaf number per plant was recorded from the plot treated with $150 \mathrm{~kg} \mathrm{~N} / \mathrm{ha} \mathrm{(42.73)} \mathrm{(table} \mathrm{1).} \mathrm{Biswas} \mathrm{et} \mathrm{al.} \mathrm{[16]}$ also reported the heights number of leaves per plant of tomato from the plot treated by $150 \mathrm{~kg} \mathrm{~N} / \mathrm{ha}$. However, application of $100 \mathrm{~kg} \mathrm{~N} / \mathrm{ha}$ was at par with $150 \mathrm{~kg} \mathrm{~N} / \mathrm{ha}$ on influencing number of leaves per plants and also using $50 \mathrm{~kg}$ $\mathrm{N} /$ ha also not different from using $0 \mathrm{~kg} \mathrm{~N} / \mathrm{ha}$ on number of leaves per plant. Many authors reported that supplementary application of nitrogen fertilizer increase number of leaves per plant [20].

Number of primary branches per plant was significantly $(\mathrm{P}<0.05)$ affected by rate of nitrogen fertilizer. The number of primary branch at 150 and $100 \mathrm{~kg} \mathrm{~N} / \mathrm{ha}$ was 5.0 and 4.93, respectively, which was reduced to 4.08 and 3.73 when 50 and $0 \mathrm{~kg} \mathrm{~N} / \mathrm{ha}$ applied, respectively. Application of $150 \mathrm{~kg}$ $\mathrm{N} /$ ha did not make significant difference in number of primary branch compared to $100 \mathrm{~kg} \mathrm{~N} / \mathrm{ha}$ but significantly different from 50 and $0 \mathrm{~kg} \mathrm{~N} / \mathrm{ha}$. Iqbal et al. [21] also reported that, application of $90 \mathrm{~kg} \mathrm{~N} /$ ha resulted in 4.33 primary branches which was in par using $100 \mathrm{~kg} \mathrm{~N} / \mathrm{ha}$ in this study. Application of $100 \mathrm{~kg} \mathrm{~N} / \mathrm{ha}$ increased the number of branches by $24.34 \%$ compared to application of $0 \mathrm{~kg} \mathrm{~N} / \mathrm{ha}$. The number of branch per plant increased with increasing nitrogen application up to optimum level. Degefa et al. [18] also reported that, as the rate of nitrogen fertilizer increased from $0-99 \mathrm{~kg} / \mathrm{ha}$, the number of primary branches in tomato increased by $28.9 \%$ compared to the nil nitrogen fertilizer application.

Table 1. Effect of nitrogen fertilizer rate on plant height, leaf number and number of primary branch of tomato.

\begin{tabular}{llll}
\hline Treatment $\mathbf{~ k g} / \mathbf{h a}$ & Plant height $(\mathbf{c m})$ & Number of leaves per plant & Number of primary branch \\
\hline 0 & $47.53 \mathrm{c}$ & $27.53 \mathrm{~b}$ & $3.73 \mathrm{c}$ \\
50 & $49.60 \mathrm{c}$ & $31.20 \mathrm{~b}$ & $4.08 \mathrm{c}$ \\
100 & $55.43 \mathrm{~b}$ & $38.60 \mathrm{a}$ & $4.93 \mathrm{ab}$ \\
150 & $61.26 \mathrm{a}$ & $42.73 \mathrm{a}$ & $5.0 \mathrm{a}$ \\
Mean & 53.46 & 35.01 & 4.44 \\
LSD $(5 \%)$ & 5.49 & 5.38 & 0.83 \\
CV $(\%)$ & 5.12 & 7.69 & 10.417 \\
\hline
\end{tabular}

Means within the same column followed by the same letter (s) are not significantly different from each other and different letters indicated significantly different at $5 \%$ level of significance.

\subsection{Effect of Nitrogen Fertilizer on Yield Components of Tomato}

Application of nitrogen fertilizer brought significant $(\mathrm{P}<0.05)$ change on number of cluster per plant of tomato. The highest number of cluster per plant was recorded from the plot received $150 \mathrm{~kg} \mathrm{~N} / \mathrm{ha}$ (20.40) followed by $100 \mathrm{~kg}$ $\mathrm{N} /$ ha (19.26) which was significantly different from the plot treated by 50 and $0 \mathrm{~kg} / \mathrm{ha}$ (Table 2). However, there was no significant difference between the plots treated by 100 and
$150 \mathrm{~kg} \mathrm{~N} / \mathrm{ha}$ in number of cluster per plant. In this study, as the nitrogen fertilizer level increased, the number of clusters per plant also increased. However, in this study, the successive rates of fertilizer were not significantly different in affecting number of cluster of tomato per plant. The most probable reason could be, tomato cluster formation do not give significant response to less or equals to $50 \mathrm{~kg} \mathrm{~N} / \mathrm{ha}$ fertilizer addition. This result was in line with the result obtained by Iqbal et al. [21]. Biswas et al. [16] also reported highest number of cluster per plant of tomato from the plot 
treated by $150 \mathrm{~kg} \mathrm{~N} / \mathrm{ha}$.

The analysis of the result demonstrated that, the various doses of nitrogen fertilizer showed non-significant on number of fruits per cluster of tomato even if the mean values were different from each other. This result was disagreed with the result revealed by Biswas et al. [16] who reported significant difference among nitrogen fertilizer levels in number of fruits per cluster but on different cultivar (BARI Tomato-9). This could be due to different variety of tomato responds differently to level of nitrogen fertilizer regarding number of fruit per clusters.

\subsection{Effect of Nitrogen Fertilizer on Fruit Yield of Tomato}

The result of analysis showed that, there was significance $(\mathrm{P}<0.05)$ difference among nitrogen fertilizer rate in influencing fruit yield of tomato per hectare (table 2). The highest fruit yield was obtained from the plot treated by 150 $\mathrm{kg} \mathrm{N} /$ ha $(28.737 \mathrm{t} / \mathrm{ha})$ which was not significantly different from the plot treated by $100 \mathrm{~kg} \mathrm{~N} / \mathrm{ha}(28.233 \mathrm{t} / \mathrm{ha})$. The lowest fruit yield $(8.393 \mathrm{t} / \mathrm{ha})$ was recorded from the plot treated by nil nitrogen fertilizer. There was significant differences between $0 \mathrm{~kg}$ and $100 \mathrm{~kg} \mathrm{~N} / \mathrm{ha}$ and between 50 and $100 \mathrm{~kg} \mathrm{~N} / \mathrm{ha}$ in influencing the yield of tomato per hectare. This result revealed the gradual increase in yield of tomato with the rate of nitrogen fertilizer up to optimum level. This study was in line with the finding of Biswas et al. [16] who reported highest fruit yield from the plot treated with $150 \mathrm{~kg} \mathrm{~N} /$ ha. Application of 150 and $100 \mathrm{~kg} \mathrm{~N} / \mathrm{ha}$ increased yield of tomato by 70.79 and $70.27 \%$, respectively, compared to the control treatment. Application of $50 \mathrm{~kg} \mathrm{~N} / \mathrm{ha}$ had 9.68t/ha yield advantage over the nil (control) fertilizer application. The result of this study was in line with result of Warner et al. [22] who reported that, as the rate of nitrogen fertilizer increased, the yield of tomato increased. Biswas et al. [16] also reported the highest fruit yield of tomato when the crop treated by $108.6 \mathrm{~kg} \mathrm{~N} / \mathrm{ha}$ at the eastern part of Ethiopian country.

Table 2. Effect of different rate of nitrogen fertilizer on number of clusters per plant, number of fruits per clusters and yield in tone per hectare of tomato.

\begin{tabular}{llll}
\hline Treatment N kg/ha & Number of cluster/plant & Number of fruit/cluster & Yield t/ha \\
\hline 0 & $13.36^{\mathrm{c}}$ & $4.5333^{\mathrm{a}}$ & $8.393^{\mathrm{c}}$ \\
50 & $14.20^{\mathrm{bc}}$ & $4.53^{\mathrm{a}}$ & $18.073^{\mathrm{b}}$ \\
100 & $19.26^{\mathrm{ab}}$ & $4.80^{\mathrm{a}}$ & $28.233^{\mathrm{a}}$ \\
150 & $20.40^{\mathrm{a}}$ & $5.06^{\mathrm{a}}$ & $28.737^{\mathrm{a}}$ \\
Mean & 16.88 & 4.73 & 20.867 \\
LSD (5\%) & 5.72 & 0.81 & 2.1941 \\
CV (\%) & 16.81 & 8.59 & 5.27 \\
\hline
\end{tabular}

Means within the same column followed by the same letter (s) are not significantly different from each other and different letter (s) indicated significantly different at $5 \%$ level of significance.

\section{Conclusion}

Soil nutrient is one of the most important factors to attain optimum yield in all crop production system. Nitrogen plays important role in vegetative and fruit development in crops. Tomato (Lycopersicon esculentum mill.) is third most important vegetable crop in the world and its production is challenged by many factors from which optimum amount of nitrogen nutrient is the primary problem particularly in Ethiopia.

This study revealed that, nitrogen fertilizer rate at 100 and $150 \mathrm{~kg}$ per hectare provided 28.233 and $28.74 \mathrm{t} / \mathrm{ha}$ fruit yield, respectively, in which there was no significant difference between the two treatments. Hence, $100 \mathrm{~kg} / \mathrm{ha}$ nitrogen fertilizer rate can be recommended for optimum yield of tomato (Roma VF variety) in the study area and the areas with similar soil type.

\section{References}

[1] FAOSTAT, 2010. Statistical data base of food and agriculture of the write donation Maria, Jose Diez and Fernano neuzh and book of plant breeding vegetable (152-156).

[2] FAO, 2014. United Nation Food and Agriculture Organization Statistics Division. Crop Production data. Rome, Italy.
[3] Kanyomeka L and Shuvite B, 2005. Influence of pruning on tomato production under controlled Environments. Agricultural Tropicaet Subtropica, 32 (2), 79-81.

[4] Ellis J G, 1998. Postharvest problems of tomato production in Ghana-Field studies of some selected major growing areas in Ghana. Journal of the Ghana science association, 1 (1), 55-59.

[5] Tesfa B, Yosef A, Jibicho G, Gebeyehu W and Melkamu H, 2016. Performance of introduced hybrid tomato (Solanum lycopersicum Mill.) cultivars in the Rift Valley, Ethiopia. International Journal of Research in Agriculture and Forestry, 3 (10), 25-28.

[6] Edossa E, Dechasa N, Alamirew T, Alemayehu Y and Desalegne L, 2013b. Household fertilizer use and soil fertility management practices in vegetables crop production in the central rift valley of Ethiopia. Science technol. Arts res. J., 2 (4), 47-55.

[7] Birhanu K and Tilahun K, 2010. Fruit yield and quality of drip-irrigated tomato under deficit irrigation. Afr. J. Food, Agric, Nutr. Dev., 10 (2), 2139-2144.

[8] FAOSTAT, 2012. Agricultural data. Provisional 2012 Production Indices Data. Crop Primary. (http://apps.fao.org/default.jsp).

[9] CSA, 2018. Report on area and production of major in Ethiopia. Centeral statistics Agency. Addis Abeba. 
[10] Desalegne L, 2002. Tomato research experience and production prospects, Ethiopian Agricultural Research Organization, 2002. Research Report 43. Addis Abeba, Ethiopia.

[11] Sanchez P A, Buresh R J, Izac A N, Place F M, and Shepherd K D, 1997. Soil fertility replenishment in Africa: SSSA Spec. Publ. 51. SSSA and ASA, Madison, WI. p. 1-46.

[12] Balemi T, 2008. Response of tomato cultivars differing in growth habit to nitrogen and phosphorus fertilizers and spacing on vertisol in Ethiopia. Acta Agric. Slov., 91 (1): 103.

[13] Fontes P C R and Ronchi C P, 2002. Critical values of nitrogen indices in tomato plants grown in soil and nutrient solution determined by different statistical procedures. Pesq. agropec. bras., Brasília, 37 (10), 1421-1429.

[14] Hokam E M, El -Hendawy S E and Schmidhalter U, 2011. Drip Irrigation Frequency: The Effects and Their Interaction with Nitrogen Fertilization on Maize Growth and Nitrogen Use Efficiency under Arid Conditions. J. Agronomy and Crop Science, 197, 186-201.

[15] Kahsay Y K, Embaye A and Tekle G, 2016. Determination of Optimum Rates of N and P Fertilizer for Tomato at Mereblekhe District, Northern Ethiopia. Journal of Agriculture and Crops, 2 (3), 24-30.

[16] Biswas M, Sarkar D R, Asif M I, Sikder R K, Mehraj H and Jamal Uddin A F M, 2015. Nitrogen Levels on Morphological and Yield Response of BARI Tomato - 9. Journal of Science,
Technology and Environment Informatics, 01 (2), 68-74.

[17] Najafvand S, Direkvandi N, Alemzadeh A and Sedighie DF, 2008. Effect of Different Levels of Nitrogen Fertilizer with Two Types of Bio-Fertilizers on Growth and Yield of Two Cultivars of Tomato (Lycopersicon esculentum Mill). Asian Journal of Plant Sciences, 7 (8), 757-761.

[18] Degefa G, Benti G, Jafar M, Tadesse F, Berhanu H (2019). Effects of Intra-Row Spacing and Fertilizer Rates on Yield and Yield Components of Tomato (Lycopersicon Esculentum L.) at Harawe, Eastern Ethiopia. Journal of Plant Sciences 7 (1): 8-12.

[19] Tisdale S L, Nelson W L, Beaton J D and Havlin J L, 2003. Soil Fertility and Fertilizers. 5th Edn., Prentice-Hall of India, New Delhi, India.

[20] Ewulo B S, Sanni K O and Adesina J M, 2015. Response of tomato (Lycopersicum esculentum var. mill) to different levels of nitrogen and phosphorus fertilizer in south western nigeria. International journal of applied and pure science and agriculture, 1 (1), 2394-5532.

[21] Iqbal M, Niamatullah M, Yousaf I, Munir M and Khan M Z, 2011. Effect of nitrogen and potassium on growth, economical yield and yield components of tomato. Sarhad J. Agric., 27 (4), 545-548.

[22] Warner J, Zhang T Q and Hao X, 2004. Effects of nitrogen fertilization on fruit yield and quality of processing tomatoes. Canadian journal of plant science, 84, 865-871. 